\title{
FORMATION OF COMPETENCE FOR THE CREATION AND USE OF ELECTRONIC LEARNING RESOURCES FOR FUTURE TEACHERS
}

\author{
Kukanbayeva Durdona \\ Shakhrisabz branch of Tashkent State Pedagogical University named after Nizami an \\ independent researcher.
}

Article DOI: $\underline{\text { https://doi.org/10.36713/epra2036 }}$

\begin{abstract}
ANNOTATION
The current stage of development of education is characterized by the interdependence of information and pedagogical teaching technologies, their optimal connection with each other, which allows to reveal the creative potential and personality of the student. In this process, textbooks play a significant role.
\end{abstract}

KEY WORDS: electronic educational resources, modern media, pedagogy, lectures, seminars, media competence, multimedia, media education.

\section{DISCUSSION}

The training form in the form of a lectureseminar has already lost its effectiveness, and practice shows that almost $50 \%$ of its time is wasted. It is important to note the following conclusions drawn from the study of foreign experience: The teacher does not act as an informant, but as a consultant, consultant, and sometimes even a student's colleague. This gives some positive results: students actively participate in the learning process, learn to think independently, promote their own views, and model relational situations.

The constant growth of information and limited training time make it necessary to intensify training, develop and apply non-traditional technologies based on the use of computing technologies with active teaching methods. The introduction of active methods is one of the main tasks of didactics, which involves the activation of the entire process, the identification of systems and methods that allow students to increase their activity by forming a positive motivational structure of cognitive activity ${ }^{1}$.

The changing information and cultural environment presents modern pedagogy with a number

1. Andreev A.A. Problems pedagogy in sovremennix informatno obrazovatelni sredax // http://www.ito.su/2002/I/1/I-1-251.html. of complex tasks that are new to society and pedagogy. The development of new information and communication technologies has changed the information environment in which human development and social work can develop. Modern media in many cases have become carriers of social norms, values and rules that people adhere to. At the same time, new information technologies have become an incentive for the development of human intelligence, a new level of storage, processing and production of information. Information literacy and media competence have become one of the most important qualities of a modern person, allowing him to navigate modern information communication, choose information that is important to him, develop his abilities and solve pressing problems.

Preserving the most important achievements of mankind, the new information culture requires the modern person to develop new intellectual activity that allows him to work more efficiently in the information world.

Peculiarities of teaching students at different educational levels impose serious restrictions on the development, structure and use of e-learning resources. The need for early training of specialists in the field of information technology and teachers of natural sciences for the development and effective use of e-learning resources is common to all levels of education.

Only a well-educated teacher can ensure the efficient use of e-learning resources in the learning process. On the other hand, the retraining of a large 
number of teachers in educational institutions is impossible without the creation of appropriate educational and methodological electronic educational resources.

When e-learning resources are available and used, the teacher can not only work, but also study, improve his skills and retraining (receive secondary education). Now, pedagogical creativity and experience can be embodied in e-learning resources and, therefore, in the pedagogical community ${ }^{2}$.

Currently, the main directions of the use of computer science in the educational process are formed, the following is a list of reductions in their use:

1) as a means of knowledge control;

2) as an independent learning tool;

3) the use of multimedia technology as an illustrative tool to explain new material to improve visibility;

4) the use of web pages (for teachers) with methodological developments, curricula, etc.

students);

5) use of online abstracts collections (for

6) the use of practical modeling of experiments on objects and processes using computer simulation;

7) training using automated systems (information, modeling and teacher);

8) teach students to develop practical skills and solve problems on the computer;

9) training in the use of ICT in the chosen field of activity or profession.

Also, an analysis of the main factors affecting the ICT application process can be distinguished by:

1) the number of exhibition classes and their equipment is growing more slowly than students;

2) Updating the educational resources of educational institutions is not carried out to the required extent. The value of specialized literature in retail is very expensive. It is difficult for teachers and students to attend conferences, prospects, or buy new teaching materials for financial reasons.

3) and not traditional ways of obtaining information among students (books, magazines, lectures) through its new channels: there is a tendency to give priority to the use of multimedia and hypertext catalogs, encyclopedias and training programs on CDs and Internet resources.

2. Mengliev Sh. Electronic Resources in Education http://www.tami.uz./matnga_kar.php?Id = 404 2014.09.16.
4) independent study of new ICT elements by students, students and teachers in specific specialties and subjects.

In order to formulate a holistic approach to the use of e-learning resources in teacher practice, the use of ICT training tools for the subject function, taking into account the interdisciplinary relationships of the use of information, ICT skills and abilities, the modularity of the course and e-learning resources, and much more. consider the main ways to use it $^{3}$.

Directions for the use of electronic educational resources of a teacher of natural sciences:

1) methodological preparation for classes and extracurricular classes in science;

2) the implementation of all types of activities and activities in science;

3) quick feedback, collecting research results for statistical reporting in the learning process;

4) acquaintance with new resources and opportunities of e-learning;

5) share experience between colleagues.

Electronic pedagogy, which arose at the end of the 20th century, was the result of new technological advances. The development of international standards for the development of e-learning systems has become an important step in the integration of technology and pedagogy. Nevertheless, these achievements did not reduce the social nature of the pedagogical process, but on the contrary, the costs of creating e-learning systems and inconsistencies in the quality of their work made this necessary.

The modern e-learning network in many respects confirmed the state of learning in the 60-70s, when it was programmed in the West. According to him, the classification and algorithmization of the learning process are at the forefront, and the ability to show the correct answers in test tasks is equated with knowledge. Recognizing the superiority of human cultural development, the modern level of pedagogical science cannot satisfy even the high level of multimedia capabilities and communication technologies.

Thus, pedagogical science has developed many models and concepts of the informationeducational system, reflecting various aspects of the use of new information technologies in education, seeking to master new tools and teaching methods provided by modern computers and communication technologies. In

\section{O.V. Зимина Печаттие и} электронной услуги издания в современном висем образования: Theory, methods, practice. - M.: Iz-vo MEI, 2013. 
our opinion, when it is necessary to look at the phenomenon of modern e-learning from a more general social position, these approaches represent only the technological aspect of new learning environments. In addition, it is necessary to take into account media education, the direction of pedagogy, which is accelerating in the West. First of all, this is due to the fact that the media are becoming more and more cultural, and the media environment is increasingly affecting the development of youth today. The concept of media education in high school should fill this gap.

\section{BIBLIOGRAPHY}

1. Andreev A.A. Problems pedagogy in sovremennix informatno obrazovatelni sredax II http://www.ito.su/2002/I/1/I-1-251.html.

2. Mengliev Sh. Electronic Resources in Education http://www.tami.uz./matnga_kar.php?Id = 404 2014.09.16.

3. О.V. Зимина Печаттие и электронной услуги издания в современном висем образования: Theory, methods, practice. - M.: Iz-vo MEI, 2013. 